\title{
Origin, Trajectory and Relationships of the Major Splancnic Nerve
}

\author{
Origen, Trayecto y Relaciones del Nervio Esplácnico Mayor \\ *Amauri Clemente da Rocha; **élio Fernando de Sousa Rodrigues; *'Luiz Ferreira de Souza; \\ **** Gustavo Jaime Clímaco Galvão \& ${ }^{* * *}$ Daniel Pacheco da Costa
}

ROCHA, A. C.; SOUSA-RODRIGUES, C. F.; SOUZA, L. F.; GALVÃO, G. J. C; COSTA, D. P. Origin, trajectory and relationships the major splancnic nerve. Int. J. Morphol., 25(4):749-753, 2007.

SUMMARY: The major splancnic nerve is part of the nervous simpathic system and is placed in the posterior mediastine heading for the abdomen to innerve the abdominal visceras, and it's anatomical knowledge is of great importance to surgical procedures on this region. A descriptive anatomical study aimed to study the origin, trajectory and relationship of the major splancnic nerve. 44 nerves from 22 adult bodies, from both sex, from no defined race and maintained in formol at $10 \%$ were dissected. Many ways of origins to the splacnic nerve were observed, with only 7 cases being concordant with the researched authors. There were 25 nerves (56\%) made from non sequenced origins. From the right nerves, $14(63,8 \%)$ from the 22 cases originated from three or four roots from the simpathic trunk. In $12(54,5 \%)$ left nerves, two or three contributions from the simpathic range were predominant. 22 nerves (16 from the right and 6 from the left) followed the descendant rout on the medial way and 22 nerves ( 6 from the right and 16 from the left) headed down following the spine side outline with no medial return. 21 nerves were found ( 6 from the right and 15 from the left) in a lateral location to the thoracic spine, 16 front-lateral nerves ( 9 from the right and 7 from the left) and 7 right nerves were anterior to the spine. We concluded there's no origin standard to the major splancnic nerve due to its large variety of origins. The major splancnic nerve may be placed in front to the thoracic spine after it's formation. Therefore, it's expected that this study may enlarge knowledge about the major splancnic nerve and reduce the risks caused by its damage in surgical procedures in the posterior mediastine.

KEY WORDS: Major splancnic nerve; Simpathic nervous system.

\section{INTRODUCTION}

The major splancnic nerve is formed by contributions from several ganglions from the simpathic trunk. The superior and inferior limits of its origin are changeable creating divergences among many authors. Its origin may be from $\mathrm{T}_{4}$ to $\mathrm{T}_{10}, \mathrm{~T}_{5}$ to $\mathrm{T}_{9}, \mathrm{~T}_{5}$ to $\mathrm{T}_{10}, \mathrm{~T}_{6}$ to $\mathrm{T}_{9}, \mathrm{~T}_{7}$ to $\mathrm{T}_{9}$ and from non sequenced origins which is the case of $T_{5}$ and $T_{9}$. After formed, it may go down through the thorax following the side or front-lateral outline of the spine until the abdomen contributing to the formation of the celiac plexus, aorticrenal and superior mesenteric. Through it, motor and sensitive fibers that contribute to the innervation of thoracic and abdominal visceras pass. Because of the differences related to its origin and relationship with the spine, added to its importance on keeping the operation of the body, determinated the aim of this study with a detailed analysis of the major splancnic nerve was chosen, which would reduce the risks of its damage improving the surgical procedures on the superior mediastine.

\section{MATERIAL AND METHOD}

A descriptive anatomic study aimed to study the origin, trajectory and relationship of the major splancnic nerve. 44 nerves from 22 adults bodies, from both sex, from no defined race and maintained in formol in $10 \%$ were dissected, belonging to the Department of Morphology of

\footnotetext{
Assistant Professor of Human Anatomy from Universidade Federal de Alagoas and Universidade Estadual de Ciências da Saúde de Alagoas (UNCISAL), Brazil.

** Professor Doctor in Human Anatomy from Universidade Federal de Alagoas (UFAL) and UNCISAL, Brazil.

*** Academic Medical School from UNCISAL, Brazil.

Scientific initiation paper financed by Fundação deAmparo à Pesquisa de Alagoas/ UNCISAL, Brazil.
} 
the State University of Health of Alagoas (UNCISAL) Brazil. Related to its origin, variables were made to the number of simpathic ganglions, to the numbers of their contributions and to the first and last ganglion that contributed to its origin; related to its trajectory, depending on the direction of the nerve, variables to the descendant placing on the medial way or descendant following the side outline of the spine without coming back on the medial way; the variables of the relationship of the nerve with the spine were defined as lateral, frontal or front-lateral.

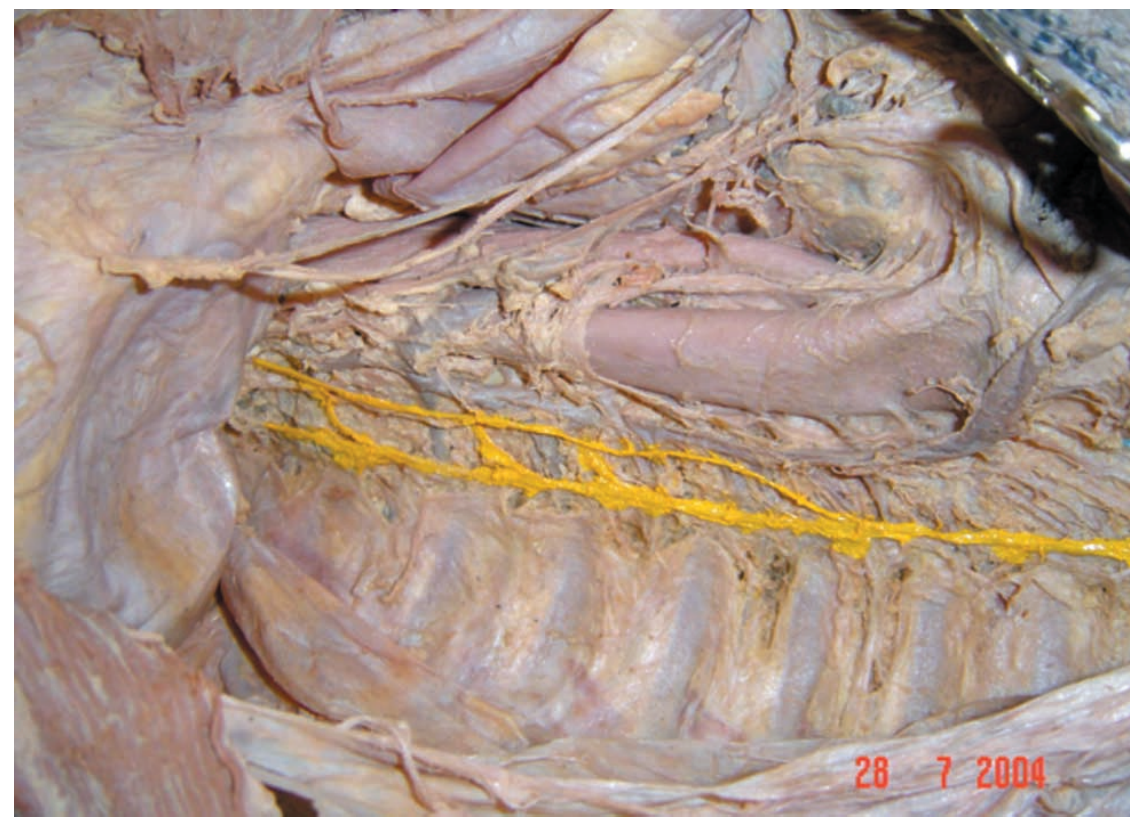

Fig. 1. Case 1. Left major splancnic nerve with origins from $\mathrm{T}_{4} \mathrm{~T}_{6} \mathrm{~T}_{7}$ and $\mathrm{T}_{8}$, on a descendent and lateral rout to the spine.

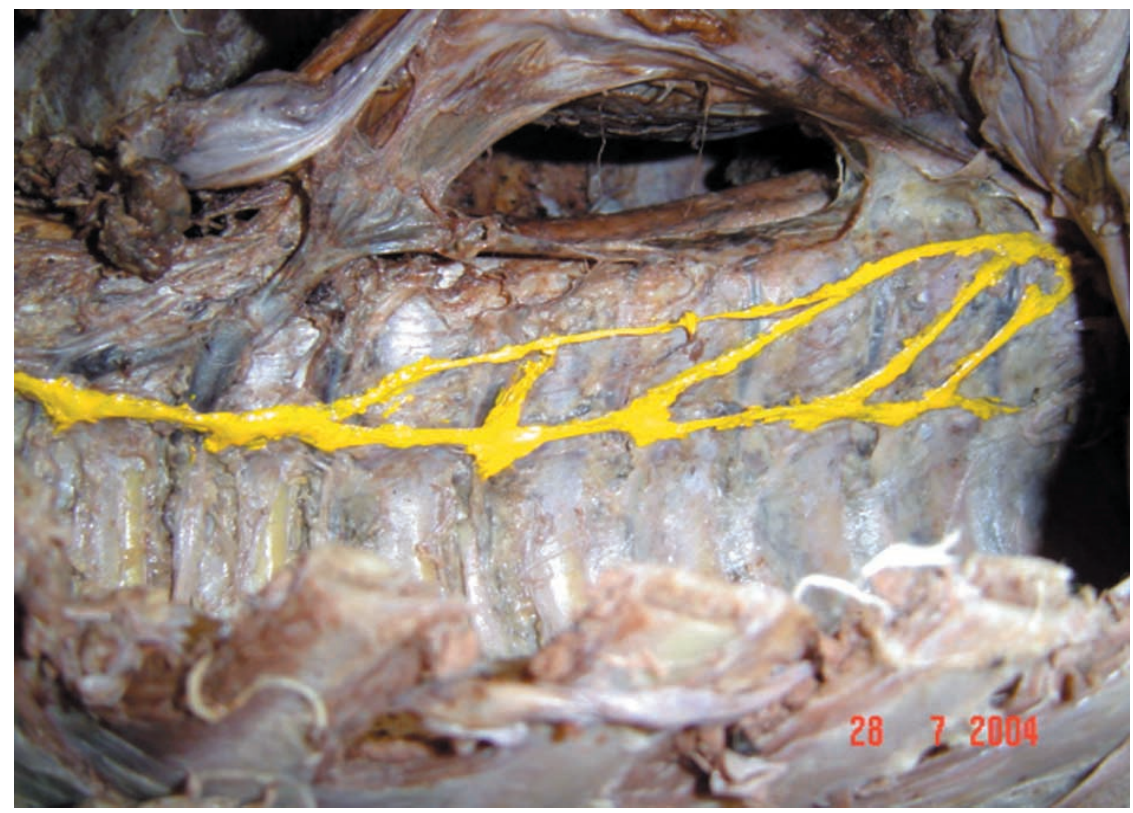

Fig. 2. Case 14. Right major splancnic nerve with origins from $T_{5}$ to $T_{9}$, on a descendent rout on the medial way and located front-lateral to the spine.

\section{RESULTS}

To a better understanding, the way of origin and contributions of the major splancnic nerves are demonstrated on Figs. 1 and 2.

Related to the rout of the nerves from the right side were evidenced 16 nerves descendently placed following the side outline of the spine without coming back on the medial way. As the left nerves, 6 headed descendently on the medial way and 16 were descendent following the side outline of the spine. As the relation with the spine, among the right nerves, 7 were frontal, 6 lateral, and 9 front-lateral; but among the left nerves, 15 were lateral, 7 were front-lateral.

\section{DISCUSSION}

The major splancnic nerve is placed on the posterior mediastine heading for the abdomen to innerve the abdominal visceras, and its anatomical knowledge is of great importance to surgical procedures on this area, such as splancnicectomy to heal the pain in chronical pancreatites (Yeo, 1999). It is part of the simpathic nervous system and contributes to the formation of three important plexus placed in the abdominal areas: celiac plex (Grant, 1948; Hamilton, 1982; Orts-Llorca, 1964; Lockhart, 1983; Moore, 2001), aortic-renal (Moore) and superior mesenteric (Gérard, 1912; Moore). Through this nerve, simpathic preganglions fibers from the side column of the thoracic spinal marrow head from the thorax for such plexus being importantly responsible for the innervation of great part of the thoracic and abdominal visceras (Gérard; Moore; Snell, 1984; Woodburne, 1984) such as aorta, esophagus, stomach, liver, gall bladder, spleen, kidneys, suprarenal, intestine and pancreas. 
ROCHA, A. C.; SOUSA-RODRIGUES, C. F.; SOUZA, L. F.; GALVÃO, G. J. C; COSTA, D. P. Origin, trajectory and relationships the major splancnic nerve. Int. J. Morphol., 25(4):749-753, 2007.

Tabla I. Demonstration of the origins of the major splancnic nerves to the right and to the left.

\begin{tabular}{|c|c|c|}
\hline CASES & Right Nerves & Left Nerves \\
\hline 1 (Fig. 1) & $\mathrm{T}_{5}$ to $\mathrm{T}_{7}$ & $\mathrm{~T}_{4}, \mathrm{~T}_{6}, \mathrm{~T}_{7}$ and $\mathrm{T}_{8}$ \\
\hline 2 & $\mathrm{~T}_{6}, \mathrm{~T}_{7}$ and $\mathrm{T}_{8}$ & $\mathrm{~T}_{5}$ to $\mathrm{T}_{9}$ \\
\hline 3 & $\mathrm{~T}_{5}$ to $\mathrm{T}_{9}$ & $\mathrm{~T}_{6}$ to $\mathrm{T}_{10}$ \\
\hline 4 & $\mathrm{~T}_{8}$ to $\mathrm{T}_{11}$ & $\mathrm{~T}_{6}$ to $\mathrm{T}_{10}$ \\
\hline 5 & $\mathrm{~T}_{6}$ to $\mathrm{T}_{9}$ & $\mathrm{~T}_{7}$ and $\mathrm{T}_{9}$ \\
\hline 6 & $\mathrm{~T}_{6}$ and $\mathrm{T}_{8}$ (two contributions) & $\mathrm{T}_{5}$ (two contributions), $\mathrm{T}_{7} \mathrm{~T}_{8}$ and $\mathrm{T}_{9}$ \\
\hline 7 & $\mathrm{~T}_{6}, \mathrm{~T}_{9}$ and $\mathrm{T}_{10}$ & $\mathrm{~T}_{6} \mathrm{~T}_{8}$ (two contributions) and $\mathrm{T}_{9}$ \\
\hline 8 & $\mathrm{~T}_{5}$ and $\mathrm{T}_{8}$ & $\mathrm{~T}_{5}$ to $\mathrm{T}_{7}$ \\
\hline 9 & $\mathrm{~T}_{6}, \mathrm{~T}_{7}, \mathrm{~T}_{9}$ and $\mathrm{T}_{10}$ & $\mathrm{~T}_{5} \mathrm{~T}_{7}$ and $\mathrm{T}_{8}$ \\
\hline 10 & $\mathrm{~T}_{4}$ to $\mathrm{T}_{9}$ & $\mathrm{~T}_{6} \mathrm{~T}_{8}$ and $\mathrm{T}_{9}$ \\
\hline 11 & $\mathrm{~T}_{7}, \mathrm{~T}_{8}$ and $\mathrm{T}_{9}$ & $\mathrm{~T}_{4} \mathrm{~T}_{6}$ (two contributions) and $\mathrm{T}_{8}$ \\
\hline 12 & $\mathrm{~T}_{7}$ (two contributions) & $\mathrm{T}_{6} \mathrm{~T}_{7}$ and $\mathrm{T}_{9}$ \\
\hline 13 & $\mathrm{~T}_{5}, \mathrm{~T}_{7}, \mathrm{~T}_{8}$ and $\mathrm{T}_{10}$ & $\mathrm{~T}_{4} \mathrm{~T}_{6}$ and $\mathrm{T}_{8}$ \\
\hline 14 (Fig. 2) & $\mathrm{T}_{5}$ to $\mathrm{T}_{9}$ & $\mathrm{~T}_{6} \mathrm{~T}_{7}$ and $\mathrm{T}_{9}$ \\
\hline 15 & $\mathrm{~T}_{4}$ to $\mathrm{T}_{9}$ & $\mathrm{~T}_{5}$ and $\mathrm{T}_{8}$ (three contributions) \\
\hline 16 & $\mathrm{~T}_{7}, \mathrm{~T}_{8}$ and $\mathrm{T}_{10}$ & $\mathrm{~T}_{7}$ and $\mathrm{T}_{9}$ \\
\hline 17 & $\mathrm{~T}_{6}$ and $\mathrm{T}_{8}$ (two contributions) & $\mathrm{T}_{6}$ and $\mathrm{T}_{7}$ \\
\hline 18 & $\mathrm{~T}_{5}, \mathrm{~T}_{8}$ and $\mathrm{T}_{9}$ & $\mathrm{~T}_{8}$ and $\mathrm{T}_{9}$ \\
\hline 19 & $\mathrm{~T}_{5}$ to $\mathrm{T}_{8}$ & $\mathrm{~T}_{7}$ and $\mathrm{T}_{8}$ \\
\hline 20 & $\mathrm{~T}_{5}, \mathrm{~T}_{7}, \mathrm{~T}_{8}$ and $\mathrm{T}_{9}$ & $\mathrm{~T}_{6}$ to $\mathrm{T}_{8}$ \\
\hline 21 & $\mathrm{~T}_{6}, \mathrm{~T}_{5} 7$ (two contributions) and $\mathrm{T}_{8}$ & $\mathrm{~T}_{5}$ to $\mathrm{T}_{9}$ \\
\hline 22 & $\mathrm{~T}_{5}, \mathrm{~T}_{7}, \mathrm{~T}_{8}$ and $\mathrm{T}_{9}$ & $\mathrm{~T}_{5}$ to $\mathrm{T}_{10}$ \\
\hline
\end{tabular}

Besides its importance for the motor innervation of such visceras, the splancnic nerve contributes to the sensitive innervation of them, as by it nervous fibers rise going to the mellow and conduit pain stimulus to the central nervous system (Gardner, 1971; Gérard).

In our study, during the dissections, we noticed that the major splancnic nerve is made by many contributions of ganglions from the simpathic trunk and the superior and inferior limits of its origin are very changeable. To Gardner, the major splancnic nerve origins from roots by the simpathic trunk usually between the fifth and the tenth ganglions, sometimes being possible, its superior limit reach the fourth ganglion. This characteristic, on the present study, was found only in one nerve among the 44 dissected having its origin from contributions of the $5^{\circ}$ to the $10^{\circ}$ ganglion.
This great variability about the origin of the major splancnic nerve, makes of him a reason for many discussions and divergences. Besides Gardner's description, other authors say that the nerve may be originated by $\mathrm{T}_{4}$ to $\mathrm{T}_{10}$ (Lockhart), $\mathrm{T}_{5}$ to $\mathrm{T}_{9}$ (Gray, 1988; Snell), $\mathrm{T}_{5}$ to $\mathrm{T}_{10}$ (Grant; Moore; Woodburne), from $\mathrm{T}_{6}$ to $\mathrm{T}_{9}$ (Gerard; Orts-Llorca; Rouvière, 1943) and from $\mathrm{T}_{7}$ to $\mathrm{T}_{9}$ (Latarjet, 1993). On the present study, we were able to notice that in 4 cases, the nerve originated as Gray and Snell described, having its origin from the ganglions $T_{5}$ a $\mathrm{T}_{9}$. In one case, as described by Latarjet, we noticed that the contributions to the origin of the nerve came from 3 ganglions $\left(\mathrm{T}_{7}, \mathrm{~T}_{8}\right.$ and $\left.\mathrm{T}_{9}\right)$ and in another one, we noticed that, as it was described by Gerard, Orts-Llorca and Rouviére, the major splancnic nerve originated from $\mathrm{T}_{6}$ to $\mathrm{T}_{9}$. 
Hamilton describes that the major splancnic nerve may have non sequenced origins of the simpathic trunk like from $\mathrm{T}_{5}$ and $\mathrm{T}_{9}$. On this study there were 25 cases $(56 \%)$ of nerves, which formed from non sequenced origins of the simpathic range.

Gardner relates that besides the great roots that contributes to the nerve formation, an inconstant number of little roots coming from the simpathic trunk may also be part on its formation. This statement can be observed on this study, taking into consideration that, several times, we have shown the differences of thickness among the contributions from the ganglions to the formation of only one nerve.

Authors as Latarjet, Gerard, Orts-Llorca and Rouvière describe the splancnic nerve as being originated from three or four roots from the simpathic root, witch were found in 14 cases $(63,8 \%)$ to the right. In 12 cases $(54,5 \%)$ to the left, on the present casuistic, being dominant in only two or three contributions of the simpathic range, leading to the formation of the major splancnic nerve, according to Hamilton and Latarjet citations.

When we talk about the number of roots or contributions that each simpathic ganglion originates, the dissections made on this study have shown that usually there's one root to each ganglion being possible to exist until three contributions from a same ganglion, showing through the linear regression test a great link both to the right as to the left, between the number of roots and the number of ganglion with statistical significance.

In one case, the major splancnic nerve originated from only one ganglion $\left(\mathrm{T}_{7}\right)$, have this one originated two roots, fact not described on records.

As the ganglion that first contributed to the origin of the nerve, it has been noticed, in our study, that in $72,7 \%$ of the right nerves and in $68,1 \%$ of the left nerves, the ganglions $\mathrm{T}_{5}$ or $\mathrm{T}_{6}$ originated the first roots. According to most of the consulted authors, theses ganglions are the main superior limits of origin of the major splancnic nerve, which could be confirmed on the present study.

The same affirmation can't be made when the inferior limit of the origin of the nerve is discussed. In our dissections, we observed $68,1 \%$ of the origins of the right nerves and $77,2 \%$ of the origins of the left nerves ended up between $\mathrm{T}_{8}$ and $\mathrm{T}_{9}$. The literature, in most of its facts, relates that usually the inferior limit of the major splancnic nerve origin is between $\mathrm{T}_{9}$ and $\mathrm{T}_{10}$.

Related to the nerve trajectory, during the dissections two possible routs were found. One of them would be the descendent rout in the medial way and the other one would be the following the side outline of the spine, without coming back on the medial way. The researched literature doesn't say specifically about each right or left nerve; however it says exactly about the two routs found. On our study, 22 nerves followed the descendent rout on the medial way as described by Gray and Latarjet and 22 nerves headed down following the side outline of the spine with no return on the medial way according to Gérard, Lockhart, Rouvière and Woodburne. From the 22 right major splancnic nerves, 16 had descendent direction with medial way and 6 showed themselves as the other form of presentation of the rout. However, when related to the left nerves, it was noticed that 6 of them had shown the descendent rout with medial way, and 16 were dissected with a descendent direction following the side outline of the spine without coming back on the medial way. We have observed that the position of most of the left nerves that had shown routs following the side outline of the spine had been very influenced by the biggest number of great structures located around the nerves, as such, heart, aorta and esophagus. This possibility could be raised because the right nerves have exactly the opposite with only 6 of them heading for the abdomen, following the side outline of the spine.

When we started noticing in our study, the relationship of the major splancnic nerve with the structures of the posterior mediastine, we came across a large variability related to the location of such organs. The only structure we consider as being important to relate with the nerve was the spine, as it is always on a maintained position in the posterior mediastine. Again, the searched literature doesn't specify the relation of the right or left nerve with the spine. This relationship is connected to the rout the nerve shows and because of this the consulted references say that the major splancnic nerve may be front-lateral or lateral to that structure. On the present study, as described by Gerard, Lockhart, Rouvière and Woodburne, we have found 21 nerves ( 6 from the right and 15 from the left) that were located on the side of the thoracic spine. But as said by Gray and Latarjet, we noticed 16 front-lateral nerves ( 9 from the right and 7 from the left). Seven right nerves from our dissections had shown an anterior relation with the spine, which wasn't found on the studied literature.

We concluded that there's no standard to the origin of the major splancnic nerve due to its origins large variability. The major splancnic nerve can be located in front of the spine after its formation as well. Therefore, we expect that this study may enlarge the knowledge about the major splancnic nerve and reduce the risks of its damage in surgical procedures on the posterior mediastine. 
ROCHA, A. C.; SOUSA-RODRIGUES, C. F.; SOUZA, L. F.; GALVÃO, G. J. C; COSTA, D. P. Origen, trayecto y relaciones del nervio esplácnico mayor. Int. J.Morphol., 25(4):749-753, 2007.

RESUMEN: El nervio esplácnico mayor es parte del sistema nervioso simpático y se ubica en el mediastino posterior, se dirige hacia el abdomen para inervar las vísceras de la región. Su conocimiento anatómico es de importancia en los procedimientos quirúrgicos que se realizan en el abdomen. Este trabajo tuvo como objetivo estudiar el origen, trayecto y relaciones del nervio esplácnico mayor Fueron disecados 44 nervios de 22 cadáveres adultos, formolizados al 10\%, de ambos sexos de diferentes razas. 25 nervios (56\%) no tenían un origen secuencial. En el lado derecho, 14 casos $(63,8 \%)$ se originaron a partir de tres o cuatro raíces del tronco simpático. En el lado izquierdo, en 12 casos (54\%), el rango de contribución simpática predominante fue de dos o tres raíces. 22 nervios (16 del lado derecho y 6 del izquierdo) siguieron su descenso medialmente y los restantes 22 nervios (6 del lado derecho y 16 del izquierdo) se dirigieron caudalmente siguiendo la columna vertebral, contorneándola lateralmente sin dirigirse hacia medial. Se encontraron 21 nervios (6 del lado derecho y 15 del izquierdo) en una ubicación lateral a la columna vertebral torácica, 16 nervios en una ubicación anterolateral ( 9 del lado derecho y 7 del izquierdo) y 7 nervios derechos ubicados anterior a la columna vertebral. Concluimos que no hay un origen estándar del nervio esplácnico mayor . El nervio esplácnico mayor puede ubicarse anterior a la columna vertebral luego de su formación. Se espera que este estudio contribuya al conocimiento del nervio esplácnico mayor y así reducir el riesgo causado por daños en los procedimientos quirúrgicos realizados en el mediastino posterior.

\section{PALABRAS CLAVE: Nervio esplácnico mayor; Sistema nervioso simpático.}

\section{REFERENCES}

Gardner, E.; Gray, D. J. \& O’Rrahilly R. Anatomia Huma$n a .3^{\mathrm{a}}$ ed. Rio de Janeiro, Guanabara Koogan, 1971. Cap. $31,357 \mathrm{p}$.

Gérard, G. Manuel d'Anatomie Humaine. Paris, Steinheil, 1912. 578p.

Grant, J.C.B. A method of anatomy descriptive and dedutive. $4^{\mathrm{a}}$ ed. Baltimore, editora, 1948. Cap 6.523p.

Gray, H \& Goss, C. M. Anatomia. 29a ed. Rio de Janeiro, Guanabara Koogan, 1988. Cap. 12.838p.

Hamilton, W. J. Tratado de anatomia humana. 2 a ed. Rio de Janeiro, Interamericana, 1982. 715p.

Latarjet, M. \& Liard, A. R. Anatomia humana. $2^{\text {a }}$ ed. São Paulo, Panamericana. 1993. V. I. Cap. 41. 418p.

Lockhart, R. D. \& Hamilton, G. F. \& Fyfe F. W. Anatomia do Corpo Humano. $2^{\mathrm{a}}$ ed. Rio de Janeiro, Guanabara Koogan, 1983. pp. 326-327.

Moore, L. K. \& Dalley, A. F. Anatomia orientada para a clínica. $4^{\mathrm{a}}$ ed. Rio de Janeiro, Guanabara Koogan, 2001. Cap. 2.267 p.

Orts-Llorca, F. O. Anatomía Humana. $3^{\mathrm{a}}$ ed. Barcelona, Científico Médica, 1964. Cap. 17.469p.

Rouvière, H. Anatomie Humaine: Descriptive et Topographique. $2^{\mathrm{a}}$ ed. Paris, Masson, 1943. pp. 780-1.
Snell, R. S. Anatomia. $2^{\mathrm{a}}$ ed. Rio de janeiro, Medsi, 1984, Cap. 3. 88p.

Woodburne, R. T. Anatomia Humana. $6^{\mathrm{a}}$ ed. Rio de Janeiro, Guanabara Koogan, 1984. Cap. 5. 288p.

Yeo, C. J. \& Cameron, J. L. O Pancreas. In: Sabiston. Tratado de cirurgia. $15^{\text {a }}$ ed. Rio de Janeiro, Guanabara Koogan, 1999. p. 1074.

Correspondence to:

Prof. Amauri Clemente da Rocha

Universidade Federal de Alagoas

Disciplina de Anatomía Topográfica

Departamento de Morfologia

Centro de Ciências Biológicas - UFAL

Praça Afranio Jorge s/n Prado

CEP 57010-060

Maceió - AL

Brazil

Email: amauri.rocha@uol.com.br

Received: 30-03-2007

Accepted: 28-08-2007 
